University of Nebraska - Lincoln

DigitalCommons@University of Nebraska - Lincoln

Faculty Publications in Food Science and Technology

Food Science and Technology Department

$7-2010$

\title{
Environment and Hybrid Influences on Food-Grade Sorghum Grain Yield and Hardness
}

Joni K. Griess

University of Nebraska-Lincoln

Stephen C. Mason

University of Nebraska-Lincoln, smason1@unl.edu

David S. Jackson

University of Nebraska-Lincoln, djackson1@unl.edu

Tomie D. Galusha

University of Nebraska-Lincoln, tgalusha1@unl.edu

Muhammad Yaseen

University of Nebraska-Lincoln

See next page for additional authors

Follow this and additional works at: https://digitalcommons.unl.edu/foodsciefacpub

Part of the Food Science Commons

Griess, Joni K.; Mason, Stephen C.; Jackson, David S.; Galusha, Tomie D.; Yaseen, Muhammad; and Pedersen, Jeffrey F., "Environment and Hybrid Influences on Food-Grade Sorghum Grain Yield and Hardness" (2010). Faculty Publications in Food Science and Technology. 111.

https://digitalcommons.unl.edu/foodsciefacpub/111

This Article is brought to you for free and open access by the Food Science and Technology Department at DigitalCommons@University of Nebraska - Lincoln. It has been accepted for inclusion in Faculty Publications in Food Science and Technology by an authorized administrator of DigitalCommons@University of Nebraska - Lincoln. 


\section{Authors}

Joni K. Griess, Stephen C. Mason, David S. Jackson, Tomie D. Galusha, Muhammad Yaseen, and Jeffrey F. Pedersen 


\title{
Environment and Hybrid Influences on Food- Grade Sorghum Grain Yield and Hardness
}

\author{
Joni K. Griess, Stephen C. Mason,^ David S. Jackson, Tomie D. Galusha, Muhammad Yaseen, \\ and Jeffrey F. Pedersen
}

\begin{abstract}
Few studies have examined grain quality of food-grade sorghum hybrids. The objective of this study was to determine the effects of environment and hybrid on grain quality of commercially available food-grade sorghums. A randomized complete block experiment with three replications was planted in 12 environments, which included the 2004 and 2005 growing seasons and irrigated and dryland water regimes in eastern, central, and west central Nebraska and a dryland low-N environment in eastern Nebraska. Environment accounted for 5 to 140 times greater variation in measured parameters than hybrid, and the hybrid $\times$ environment interaction accounted for less than 2\% of the total variation. Grain yield and kernel mass varied, with low yields of $1.4 \mathrm{Mg} \mathrm{ha}^{-1}$ and kernels weighing $9.5 \mathrm{~g} 1000$ kernels $^{-1}$ in the low-N 2004 environment, high grain yields of $10.5 \mathrm{Mg} \mathrm{ha}^{-1}$ under irrigated conditions in central Nebraska in 2005, and kernels weighing $27.8 \mathrm{~g} 1000$ kernels $^{-1}$ in the eastern Nebraska dryland 2005 environment. Harder grain was produced in 2005 than in 2004, with the west central and central 2005 environments having the lowest tangential abrasive dehulling device (TADD) removals of $14 \%$. Non-food-grade hybrids produced higher grain yields and kernel mass than food-grade hybrids. Grain hardness was greater for nonfood-grade and medium maturity hybrids when environmental means were lower (i.e., softer) but showed little or no difference in hardness when environmental means were high. Nebraska production environments have the capability to produce high quality food-grade sorghums for specific food uses to benefit both the producer and the food processor.
\end{abstract}

J.K. Griess, S.C. Mason, and T.D. Galusha, Dep. of Agronomy and Horticulture, D.S. Jackson, Dep. of Food Science and Technology, and M. Yaseen, Dep. of Statistics, Univ. of Nebraska, Lincoln, NE 68583; J.F. Pedersen, USDA-ARS Grain, Forage and Bioenergy Research Unit, 314 Biochem, Lincoln, NE 68583. Joint contribution of the Dep. of Agronomy and Horticulture and Agricultural Research Division, Univ. of Nebraska, and USDA-ARS Grain, Forage and Bioenergy Research Unit, with partial funding from the Nebraska Grain Sorghum Promotion Board and INTSORMIL, project DAN 1254-G-0021, funded by the United States Agency for International Development, Washington, D.C. The use of trade, firm, or corporation names in this publication (or page) is for the information and convenience of the reader. Such use does not constitute an official endorsement or approval by the USDA or the Agricultural Research Service of any product or service to the exclusion of others that may be suitable. Received 25 Aug. 2009. ${ }^{\star}$ Corresponding author (smason1@unl.edu).

Abbreviations: TADD, tangential abrasive dehulling device.

$\mathrm{D}$ ROUGHT TOLERANCE (Hattendorf et al., 1988), high nutrient use efficiency (Maranville et al., 1980), and use as feed and forage for livestock (Kriegshauser et al., 2006) results in grain sorghum being an important crop in the Central Great Plains of the United States. Interest in food-grade (i.e., bright white grain, tan plant free from dark staining glumes) sorghum for use in human food products may increase the importance of grain sorghum (Rooney, 1996) and has generated the need for research about the effects of hybrid, environment, and production practices on grain yield and quality of food-grade sorghum. In Africa and Asia, sorghum grain is used as food to make thin or stiff porridges and fermented beverages (Lochte-Watson et al., 2000). In Central America and southern Mexico it is often used as a partial replacement for maize

Published in Crop Sci. 50:1480-1489 (2010).

doi: 10.2135/cropsci2009.08.0463

Published online 20 Apr. 2010.

(C) Crop Science Society of America | 5585 Guilford Rd., Madison, WI 53711 USA

All rights reserved. No part of this periodical may be reproduced or transmitted in any form or by any means, electronic or mechanical, including photocopying, recording, or any information storage and retrieval system, without permission in writing from the publisher. Permission for printing and for reprinting the material contained herein has been obtained by the publisher. 
in tortilla production (Almeida-Dominguez et al., 1991) and for wheat in leavened or unleavened breads (Rooney and Awika, 2005). Food-grade white sorghum can lead to reduced color, shorter conversion and runoff times, and improved yields for brewing (Figueroa et al., 1995). The bland taste of sorghum flour that will readily accept new flavors makes sorghum a desirable grain for many types of snack foods (Rooney, 1996). Sorghum flour is also gluten free, making it a desirable food product for humans with gluten intolerance (Fasano and Catassi, 2001), and many hybrids have high levels of antioxidants and dietary fiber (Rooney and Awika, 2005).

Little research has been conducted comparing the environment and agronomic practice influence on grain quality of sorghum hybrids. Sorghum grain yield and protein concentration are increased by increasing $\mathrm{N}$ supply (Kaye et al., 2007; Kamoshita et al., 1998). High temperatures and water stress results in lower starch concentrations (Johnson, 2005), and an increased N supply has been associated with increased kernel hardness (Kaye et al., 2007). Irrigation has been shown to result in softer kernels (Taylor et al., 1997). In general, dry milling and alkaline cooking for human food products is better with hard kernels (Johnson, 2005; Shandera et al., 1997), while wet millers and brewers prefer softer kernels with lower protein concentrations (Fox et al., 1992). The determination of grain yield and hardness of food-grade sorghum hybrids grown in different production environments would assist grain merchandisers, farmers, and food processors in targeting environments and hybrids for value-added end-use markets.

The objective of this research was to determine the magnitude of environment and hybrid effects on foodgrade sorghum grain yield, hardness, and starch and protein concentrations. These results help relate grain yield, hardness, and starch and protein concentration to the best production areas and hybrids for dry-milled food products for the relatively new and small food-grade market that has potential for growth in the near future.

\section{MATERIALS AND METHODS}

Field experiments were conducted in 12 Nebraska environments, with each location-year combination being considered an environment. The environments were selected to represent an array of environments typical for sorghum production in Nebraska. Eastern Nebraska experiments were conducted at the University of Nebraska Agricultural Research and Development Center (ARDC) near Mead, NE, under furrow irrigation, dryland, and dryland with low-N environments in 2004 and 2005. Central Nebraska experiments were conducted on dryland and with furrow irrigation at the South Central Agricultural Laboratory (SCAL), near Clay Center, NE, and in a farmer's dryland field at Hebron, NE, in 2004 and 2005. In 2005, a dryland location in west-central Nebraska was added near Orleans, NE. Monthly average temperatures and precipitation totals for each environment during the course of the experiment, as well as 30-yr averages for each environment, are shown (Tables 1 and 2).

All commercial food-grade sorghum hybrids available in 2004 and adapted to Nebraska were included in the experiment. Nine commercial food-grade hybrids and six commercial non-food-grade hybrids with maturity range classifications similar to the food-grade hybrids were used as checks (Table 3). In addition, Macia, a white grain, tan plant sorghum variety from Africa was used as a high grain quality food-grade check (Dlamini et al., 2007).

Planting date depended on soil temperature and rainfall, with all experiments planted between 22 May and 10 June in both years. Sorghum was planted in 4-row plots $7.6 \mathrm{~m}$ in length with rows spaced $76 \mathrm{~cm}$ apart. Plant populations varied from 24,000 to 44,000 seeds $\mathrm{ha}^{-1}$ depending on expected precipitation and availability of irrigation. The previous crop in all environments was soybean [Glycine max (L.) Merr.], except in the Mead low-N environments, where the previous crop was oats (Avena sativa L.), and at Orleans, where the previous crop was wheat (Triticum aestivum L.). Gravity irrigation was

Table 1. Average monthly temperatures at weather stations closest to the experimental locations ${ }^{\dagger}$ in 2004 and $2005 .^{\ddagger}$

\begin{tabular}{|c|c|c|c|c|c|c|}
\hline \multirow[b]{2}{*}{ Location and year } & \multicolumn{6}{|c|}{ Temperature } \\
\hline & May & June & July & August & September & October \\
\hline & & & & & -3 & + \\
\hline Mead 2004 & 17.8 & 20.0 & 22.2 & 21.1 & 20.6 & 12.2 \\
\hline Mead 2005 & 16.1 & 23.9 & 25.6 & 23.3 & 21.1 & 12.2 \\
\hline Mead 30-year average & 16.4 & 21.9 & 24.2 & 22.9 & 18.2 & 11.2 \\
\hline Clay Center 2004 & 16.7 & 20.0 & 22.8 & 21.1 & 21.1 & 12.2 \\
\hline Clay Center 2005 & 16.7 & 22.8 & 25.0 & 23.9 & 21.1 & 12.8 \\
\hline Clay Center 30-year average & 15.9 & 21.7 & 23.7 & 23.1 & 18.2 & 11.5 \\
\hline Hebron 2004 & 17.2 & 20.6 & 22.8 & 21.7 & 21.7 & 12.8 \\
\hline Hebron 2005 & 16.7 & 23.9 & 26.1 & 24.4 & 21.1 & 12.2 \\
\hline Hebron 30-year average & 16.7 & 22.3 & 25.2 & 24.0 & 19.1 & 12.0 \\
\hline Orleans 2005 & 15.0 & 21.7 & 25.0 & 22.8 & 20.6 & 12.2 \\
\hline Alma 30-year average & 18.4 & 23.9 & 26.5 & 25.4 & 19.7 & 13.0 \\
\hline
\end{tabular}

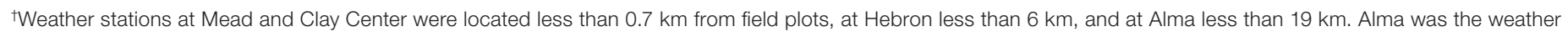
station closest to field plots in Orleans.

¥Source: High Plains Climate Center, Lincoln, NE. 
Table 2. Average monthly precipitation at weather stations closest to the experimental locations ${ }^{\dagger}$ in 2004 and 2005..

\begin{tabular}{|c|c|c|c|c|c|c|c|}
\hline \multirow[b]{2}{*}{ Location and year } & \multicolumn{7}{|c|}{ Precipitation } \\
\hline & May & June & July & August & September & October & Total \\
\hline Mead 2004 & 10.2 & 6.8 & 5.9 & 2.5 & 8.9 & 1.8 & 36.1 \\
\hline Mead 2005 & 10.2 & 8.3 & 10.5 & 3.0 & 3.2 & 4.5 & 39.7 \\
\hline Mead 30-year average & 7.4 & 10.3 & 10.1 & 8.7 & 8.4 & 7.0 & 51.9 \\
\hline Clay Center 2004 & 14.0 & 8.6 & 10.1 & 3.4 & 7.1 & 2.0 & 45.3 \\
\hline Clay Center 2005 & 7.2 & 9.0 & 8.1 & 8.2 & 2.2 & 4.4 & 39.0 \\
\hline Clay Center 30-year average & 9.9 & 10.1 & 9.7 & 8.0 & 6.4 & 6.4 & 49.1 \\
\hline Hebron 2004 & 14.7 & 16.5 & 6.2 & 3.5 & 5.4 & 1.4 & 47.9 \\
\hline Hebron 2005 & 2.6 & 8.1 & 10.1 & 12.3 & 8.3 & 5.8 & 47.2 \\
\hline Hebron 30-year average & 7.5 & 10.8 & 10.0 & 10.6 & 9.0 & 6.5 & 54.4 \\
\hline Orleans 2005 & 10.2 & 11.0 & 3.8 & 9.2 & 1.1 & 4.5 & 39.9 \\
\hline Alma 30-year average & 10.3 & 9.8 & 10.7 & 7.7 & 5.1 & 3.7 & 47.3 \\
\hline
\end{tabular}

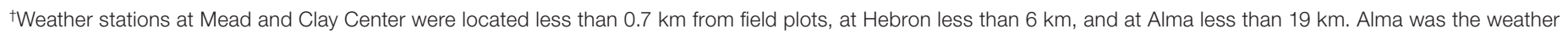
station closest to field plots in Orleans.

¥Source: High Plains Climate Center, Lincoln, NE.

applied in irrigated environments based on physical observation of crop stress and soil water content using the feel method (USDA, 1998). All soils were high water holding capacity silt loam to silty clay loam soils with 18 to $32 \mathrm{~g} \mathrm{~kg}^{-1}$ organic matter and had sufficient levels of all nutrients except $\mathrm{N}$ for sorghum grain production (Wortmann et al., 2006). The amount of $\mathrm{N}$ applied varied based on expected yield, soil $\mathrm{NO}_{3}-\mathrm{N}$ level, and whether low-N status was a planned treatment. Weed control was obtained by herbicide application and cultivation.

Grain yield was determined by machine harvest of the inner rows of each plot in all environments and adjusted to $14 \%$ water content. A modified John Deere 3300 combine (Moline, IL) with Model 453 row crop head was used to harvest Mead environments, and a modified Gleaner K2 combine (Independence, MO) was used at Clay Center, Hebron, and Orleans. Before machine harvest, 15 to 20 sorghum panicles were hand harvested from each plot. Each hand-harvested sample was threshed using a belt thresher and stored at $10^{\circ} \mathrm{C}$ until tested for grain quality characteristics. The weight of each hand-harvested sample was added back into the machine harvest grain yield of each plot. Thousand-kernel weights were determined by weighing 200 kernels in duplicate and multiplying by five.

Grain quality assessment for hardness consisted of bulk density (test weight), using a Grain Analysis Computer 2100 (DICKEY-john Corporation, Auburn, $\mathrm{IL}^{1}$ ), and true density, using a multipycnometer MVP-6DC (Quantachrome Instruments, Boyntown Beach, FL) and tangential abrasive dehulling device (TADD; model 4E-22, Venebles Machine Works, Saskatoon, SK) as described by Kaye et al. (2007). Bulk density (test weight) was defined as the mass of a volume of grain including the air space, while true density was defined as the mass of a unit of grain volume without air space (Wilhelm et al., 2004). The TADD test was administered by milling $40-\mathrm{g}$ samples of sorghum grain for $2 \mathrm{~min}$ to measure the percent removal. Low TADD removals and high bulk and true densities indicate hard kernels desirable for dry milling and alkaline-cooked food uses (Johnson, 2005; Shandera et al., 1997). Fifteen-gram samples were evaluated for protein (Padmore, 1990) and starch (Hall, 2001) concentrations by Ward Laboratory, Kearney, NE.
Table 3. Characteristics of grain sorghum hybrids used.

\begin{tabular}{lc}
\hline \multicolumn{1}{c}{ Hybrid } & Maturity class $^{\dagger}$ \\
\hline Food-grade: & Late \\
Sorghum Partners NK 8828 & Medium \\
Asgrow Eclipse & Medium \\
Asgrow Orbit & Late \\
Kelly Green Seed KG6902 & Medium \\
Fontanelle W-1000 & Medium \\
NC+ 7W92 & Medium \\
Sorghum Partners NK 1486 & Medium \\
Dekalb 44-41 & Late \\
Mycogen 14665 & \\
Food-grade check: & \\
Macia & Medium \\
Non-food-grade (checks): & \\
Dekalb 54-00 & \\
Dekalb 42-20 & Late \\
Dekalb 53-11 & Medium \\
NC+ 6C69 & Medium \\
Pioneer 84Y00 & Medium \\
Mycogen 3696 & Late \\
\hline
\end{tabular}

${ }^{\dagger}$ Medium $<72 \mathrm{~d}$ to midbloom and Late $>72 \mathrm{~d}$ to midbloom based on company classification and flowering in Mead irrigated environments.

The experiment was conducted as a randomized complete block experiment with three replications in each environment. Data were analyzed by ANOVA using SAS mixed model (Littell et al., 1996). Environments and hybrids were considered fixed effects in the model, while block effects within an environment were considered random. Homogeneity of variances was not a problem due to the balanced experimental design with equal number of replications and the fact that the environment and hybrid effects were fixed (Scheffé, 1959; Montgomery, 2005). Preplanned single degree of freedom contrasts based on the research design, some being orthogonal and others not, and LSDs $(p=0.05)$ were used to separate the main effect means for all parameters measured, and Pearson correlation coefficients were calculated to determine the relationship 
among yield, kernel mass, hardness parameters, and protein and starch concentrations. Environment $\times$ hybrid interaction effects were partitioned into logical components of food-grade and non-food-grade hybrids and hybrid maturity and were tested by ANOVA and graphed on environmental means to assist with interpretation (Budak et al., 1995).

\section{RESULTS AND DISCUSSION}

\section{Climate}

Average monthly temperatures during the growing seasons were similar in both years (Table 1); temperatures in June and July, however, were lower than the long-term average in 2004 and higher than the long-term average in 2005, except at Orleans. Growing season precipitation across environments ranged from 36 to $47 \mathrm{~cm}$ (Table 2), slightly lower than the 45 to $52 \mathrm{~cm}$ considered adequate for sorghum production in the Central Great Plains (Hattendorf et al., 1988). The Mead 2004 and 2005, Hebron 2004, and Orleans 2005 environments received the least precipitation in July and August, when the critical flowering and early grain fill growth stages (Garrity et al., 1983; Hattendorf et al., 1988) occurred. Based on higher average temperatures (Table 1), lower precipitation during July and August (Table 2), and higher estimated relative evapotranspiration (data not presented), the 2005 growing season was more stressful than 2004, and the Orleans 2005 environment was the most stressful.

\section{Environment Effects}

\section{Yield and Kernel Mass}

Magnitude of the mean squares indicated that environment had a 60 times greater effect on yield and five times larger effect on kernel mass than did hybrid (Table 4). Average grain yield ranged from 1.4 to $10.5 \mathrm{Mg} \mathrm{ha}^{-1}$ for the 12 environments (Table 5), with the highest yields usually present in irrigated environments and the lowest yields in dryland environments (Table 6), especially in the Mead dryland with low N environment in 2004 and 2005 and the Clay Center dryland 2004 environments (Table 5). Grain yields were higher in 2005 than 2004 and higher at Clay Center than Mead, and dryland yields were higher at Hebron than at Clay Center and lower at Orleans than in other dryland environments in 2005 (Table 6). The Clay Center dryland 2005 environment produced yields equivalent to irrigated conditions, probably the result of relatively uniform precipitation distribution throughout the growing season (Table 2).

Kernel mass was heaviest in dryland environments (Tables 5 and 6) where the seeding rates were lower, which was consistent with previous studies (Kiniry, 1988; Maman et al., 2004) that indicated an inverse association between the number of plants and/or panicles per square meter and kernel mass. Kernel mass was greater in 2005 than 2004 (Table 6), except at the Clay Center irrigated environment, which produced heavier kernels in 2004 than in 2005 (Table 5). Variation in kernel mass was greater in 2004, largely due to the Mead 2004 low-N environment having a lower $\mathrm{N}$ status than in 2005. Mead had heavier kernel mass than Clay Center (Table 6).

\section{Hardness}

Magnitude of mean squares indicated that main effect of environments had a 140, 61, and 81 times greater effect on bulk density, true density, and TADD removal, respectively, than did hybrid (Table 4). Bulk and true densities were greater in 2005 and TADD removal less in 2004 (Table 6), indicating harder kernels were produced in 2004. This was probably due to greater precipitation during flowering and grain fill in 2005 than 2004 (Table 3) and warmer temperatures in July, August, and September in 2004 (Table 1), consistent with other research that has shown production of harder kernels when more water and/or heat stress is present (Johnson, 2005; Taylor et al., 1997). Irrigated environments produced slightly higher bulk densities, but no differences were detected for other hardness parameters (Table 6). Mead produced slightly higher bulk densities than Clay Center, and Orleans produced slight lower TADD removal than the other locations in 2005.

Mead dryland with low-N environments in 2004 and 2005 produced kernels that were less dense than other environments each year, more so in 2004 when $\mathrm{N}$ was more limiting than in 2005 (Table 5). The Mead 2004 dryland low-N environment also had the lowest bulk density and highest TADD removal. Orleans and Hebron dryland environments in 2005 produced kernels with the smallest TADD removals (i.e., hardest kernels). These environments had similar temperatures and total precipitation (Tables 1 and 2) with the exception of Orleans. Research with sorghum and maize has shown that kernel density is greater under dryland conditions than irrigated conditions and that increased $\mathrm{N}$ rate increases kernel density (Taylor et al., 1997; Kniep and Mason, 1989; Bauer and Carter, 1986; Duarte et al., 2005). Johnson (2005) found harder sorghum kernels produced under drier Texas growing conditions than in Kansas and Nebraska.

\section{Starch and Protein Concentration}

Magnitude of the mean squares indicated environment had a six to eight times greater effect on protein and starch concentrations than did hybrid (Table 4). Protein concentration was greater in 2004, while starch concentration was higher in 2005 (Table 6), consistent with the expected inverse relationships between protein concentration and grain yield (Table 5; Bewley and Black, 1994; Duvick and Cassman, 1999; McDermitt and Loomis, 1981) and starch and protein concentrations (McDermitt and Loomis, 
Table 4. Degrees of freedom and mean squares for environment and hybrid effects on sorghum grain yield and quality.

\begin{tabular}{|c|c|c|c|c|c|c|c|c|}
\hline \multirow[b]{2}{*}{ Source } & \multirow[b]{2}{*}{ df } & \multirow[b]{2}{*}{ Yield } & \multicolumn{6}{|c|}{ Mean squares } \\
\hline & & & Kernel mass & Bulk density & True density & TADD $^{\dagger}$ & Starch & Protein \\
\hline Environment (E) & 11 & $413^{\star \star}$ & $1062^{\star \star}$ & $127,850^{\star \star}$ & $0.1505^{\star \star}$ & $10,484^{\star \star}$ & $14,324^{\star \star}$ & $6312^{* *}$ \\
\hline Error A & 24 & 2 & 6 & 517 & 0.0003 & 21 & 297 & 325 \\
\hline Hybrid $(\mathrm{H})$ & 15 & $7^{\star \star}$ & $212^{\star \star}$ & $870^{\star \star}$ & $0.0025^{\star \star}$ & $260^{\star \star}$ & $1751^{\star \star}$ & $899^{* *}$ \\
\hline $\mathrm{E} \times \mathrm{H}$ & 165 & $2^{\star \star}$ & $10^{\star \star}$ & $714^{\star \star}$ & $0.0007^{\star \star}$ & $46^{\star \star}$ & $203^{\star \star}$ & $67^{\star \star}$ \\
\hline Food-grade versus non-food-grade & 11 & $2^{*}$ & $10^{\star *}$ & $669^{\star *}$ & $0.0001^{* *}$ & $66^{\star \star}$ & 140 & $67^{\star}$ \\
\hline Medium versus late maturity & 11 & $4^{\star \star}$ & $10^{\star \star}$ & $997^{\star \star}$ & $0.0008^{\star \star}$ & $67^{\star \star}$ & 122 & $72^{*}$ \\
\hline Residual ${ }^{\ddagger}$ & $353-358$ & 1 & 3 & 145 & 0.0001 & 11 & 121 & 37 \\
\hline
\end{tabular}

*Significant at $p \leq 0.05$.

**Significant at $p \leq 0.01$.

TTADD, tangential abrasive dehulling device.

‡Residual df varied due to limited grain mass from some plots making it impossible to conduct all quality tests. These were treated as missing plots.

Table 5. Environment influence on sorghum grain yield and yield components, hardness parameters, and starch and protein concentrations (averaged over 16 hybrids).

\begin{tabular}{|c|c|c|c|c|c|c|c|}
\hline Environment & Yield & Kernel mass & Bulk density & True density & TADD $^{\dagger}$ & Protein & Starch \\
\hline & $\mathrm{Mg} \mathrm{ha}^{-1}$ & g 1000 kernels $^{-1}$ & $\mathrm{~kg} \mathrm{~m}^{-3}$ & $\mathrm{~g} \mathrm{~mL}^{-1}$ & \% removed & $-\mathrm{g} \mathrm{H}$ & $y^{-1}$ \\
\hline \multicolumn{8}{|l|}{ 2004: } \\
\hline Mead dryland low-N & 1.4 & 9.5 & 605 & 1.177 & 73 & 98 & 640 \\
\hline Clay Center dryland & 3.3 & 21.4 & 774 & 1.352 & 20 & 112 & 690 \\
\hline Hebron dryland & 5.8 & 19.5 & 760 & 1.325 & 27 & 98 & 704 \\
\hline Mead irrigated & 10.4 & 24.3 & 759 & 1.354 & 21 & 99 & 704 \\
\hline Clay Center irrigated & 10.1 & 24.0 & 794 & 1.356 & 21 & 99 & 699 \\
\hline \multicolumn{8}{|l|}{ 2005: } \\
\hline Mead dryland low-N & 5.4 & 24.7 & 800 & 1.363 & 22 & 77 & 714 \\
\hline Clay Center dryland & 9.5 & 24.4 & 798 & 1.376 & 19 & 99 & 701 \\
\hline Mead dryland & 8.4 & 27.8 & 808 & 1.375 & 17 & 109 & 701 \\
\hline Hebron dryland & 8.4 & 25.6 & 804 & 1.376 & 14 & 101 & 695 \\
\hline Orleans dryland & 7.2 & 25.2 & 804 & 1.373 & 14 & 125 & 688 \\
\hline Mead irrigated & 9.5 & 24.8 & 805 & 1.370 & 18 & 108 & 698 \\
\hline Clay Center irrigated & 10.5 & 22.0 & 798 & 1.377 & 17 & 111 & 707 \\
\hline LSD (0.05) & 0.41 & 0.71 & 8.5 & 0.0051 & 1.42 & 5.6 & 5.4 \\
\hline
\end{tabular}

TTADD, tangential abrasive dehulling device.

Table 6. Environment contrast comparisons for yield and grain quality of sorghum.

\begin{tabular}{|c|c|c|c|c|c|c|c|}
\hline Contrast comparisons & Yield & Kernel mass & Bulk density & True density & TADD $^{\dagger}$ & Protein & Starch \\
\hline & $\mathrm{Mg} \mathrm{ha}^{-1}$ & g 1000 kernels $^{-1}$ & $\mathrm{~kg} \mathrm{~m}^{3}$ & $\mathrm{~g} \mathrm{~mL}^{-1}$ & $\%$ removed & \multicolumn{2}{|c|}{$\mathrm{g} \mathrm{kg}^{-1}$} \\
\hline 2004 versus & 6.2 & 19.7 & 748 & 1.317 & 32 & 103 & 689 \\
\hline 2005 & 8.7 & 24.2 & 801 & 1.372 & 18 & 99 & 703 \\
\hline$p$-value & $<0.01$ & $<0.01$ & $<0.01$ & $<0.01$ & $<0.01$ & $N S^{\ddagger}$ & $<0.01$ \\
\hline Irrigated versus & 10.0 & 23.4 & 799 & 1.368 & 19 & 106 & 701 \\
\hline Dryland & 7.0 & 24.6 & 793 & 1.368 & 19 & 107 & 697 \\
\hline$p$-value & $<0.01$ & $<0.01$ & 0.04 & NS & NS & NS & 0.05 \\
\hline Mead versus & 9.4 & 25.7 & 790 & 1.366 & 19 & 105 & 701 \\
\hline Clay Center & 10.0 & 23.5 & 797 & 1.370 & 19 & 103 & 703 \\
\hline$p$-value & $<0.01$ & $<0.01$ & 0.03 & NS & NS & NS & NS \\
\hline Dryland Clay Center versus & 6.4 & 22.9 & 786 & 1.364 & 19 & 106 & 695 \\
\hline Hebron & 7.1 & 22.5 & 782 & 1.351 & 21 & 99 & 699 \\
\hline$p$-value & $<0.01$ & NS & NS & $<0.01$ & NS & 0.02 & NS \\
\hline 2005 Orleans versus & 7.2 & 25.2 & 804 & 1.373 & 14 & 125 & 688 \\
\hline Other locations & 8.7 & 24.9 & 803 & 1.376 & 17 & 103 & 699 \\
\hline$p$-value & $<0.01$ & NS & NS & NS & $<0.01$ & $<0.01$ & $<0.01$ \\
\hline
\end{tabular}

†TADD, tangential abrasive dehulling device.

‡NS, not significant. 
1981). Total precipitation was less than long-term averages in both years but greater and better distributed in 2005 than 2004 (Table 2).

Protein concentrations were higher at the Clay Center than the Hebron dryland environments and starch concentration was greater in dryland than irrigated environments (Table 6). The Orleans 2005 environment produced grain with higher protein and lower starch concentrations than other environments in 2005. Protein concentrations were highest at the Orleans 2005 environment followed by the Mead and Clay Center dryland environments in 2004 (Table 5). Reduced starch concentrations in the Mead dryland with low-N 2004 and Orleans 2005 environments can be attributed to stress (Tables 1 and 2) received during grain fill (Bewley and Black, 1994), especially at Orleans in 2005. This stress is also reflected by lower grain yields (Table 5). The 2005 environments had a larger range for protein concentrations among environments than 2004, but the averages were similar between years (Table 6).

Mead dryland with low N in 2004 and 2005 along with Hebron 2004 had the lowest average protein concentrations (Table 5). Low protein concentrations were expected in low- $\mathrm{N}$ environments since increased $\mathrm{N}$ application has been shown to increase the amount of protein in grain (Hanson et al., 1988; Kaye et al., 2007). Increased starch concentrations in the Mead dryland with low-N environments in 2005 were driven by high July rainfall (Table 2) and average temperatures close to the long-term average in August (Table 1), as reported by Bewley and Black (1994), as well as reduced $\mathrm{N}$ applications.

\section{Hybrid Effects}

\section{Yield and Kernel Mass}

Food-grade sorghum hybrids produced lower grain yields than the non-food-grade hybrids, but the food-grade hybrids Kelly Green Seed KG6902, Fontanelle W-1000, and Mycogen 14665 yielded as well as the highest yielding non-food-grade hybrids (Table 7). The food-grade check variety Macia produced lower yield than the foodgrade hybrids, which was expected due to lower heterosis in varieties than hybrids (Duvick, 2005). Late-maturity hybrids produced higher yields than medium-maturity hybrids, both for food-grade and non-food-grade hybrids (Table 8), as previously reported (Saeed et al., 1984).

Food-grade hybrids had lighter kernel mass than the non-food-grade hybrids (Table 8), but several individual food-grade hybrids had kernel mass equal to non-foodgrade hybrids (Table 7), suggesting that grain produced by non-food-grade hybrids might have higher fat and protein concentrations and nutritional value than grain produced by food-grade hybrids (Kriegshauser et al., 2006). Given the lower research investment made in developing commercial food-grade sorghum hybrids, it is not surprising to find lower average grain yields and kernel mass for foodgrade hybrids. However, the results indicate that with careful hybrid selection, food-grade sorghum producers can identify hybrids that produce high yield and have heavy kernels equal to those of non-food-grade hybrids (Table 7). From the food-grade hybrids used in this experiment, both Kelly Green Seed KG6902 and Dekalb 44-41 produced high yields and heavy kernels.

\section{Hardness}

On average, food-grade hybrids produced softer kernels than did non-food-grade hybrids, as was shown with lower bulk and true densities and higher TADD removal (Table 8). Late-maturity hybrids tended to produce kernels with lower TADD removal than medium-maturity hybrids but higher bulk density. However, considerable variation occurred among hybrids within both food-grade and non-food-grade hybrids (Table 7). The non-food-grade hybrid Dekalb 42-20 had the highest bulk density of all hybrids, Dekalb 42-20, NC+6C69, and Macia had the highest true densities among all hybrids, and Macia, Dekalb 42-20, and Pioneer 84Y00 had lowest TADD removals indicating production of hard grain. The hardest food-grade hybrid was Asgrow Orbit, but it had lower bulk and true densities and greater TADD removal than Macia and the best non-food-grade hybrids. The non-food-grade hybrids had the highest average true densities, but individually the non-food-grade hybrid $\mathrm{NC}+6 \mathrm{C} 69$ and the food-grade check variety Macia had the highest true density among all hybrids. These results indicate that many food-grade sorghum hybrids have the desired grain and plant color for food products but, from a hardness perspective, are less desirable for producing food products than many non-food-grade hybrids. Among the food-grade hybrids, Asgrow Orbit had the hardest grain with the highest bulk density, one of the highest true densities, and one of the lowest TADD removals, so it would be a good hybrid for food use (Johnson, 2005). The food-grade hybrids Fontanelle W-1000, NC+7W92, and NK1486 had the softest kernels, and thus would be more appropriate for use in brewing (Figueroa et al., 1995) or wet milling (Johnson, 2005).

Protein concentrations between food-grade and nonfood-grade hybrids were similar, while Macia had higher protein concentration than the food-grade hybrids (Table 8). Medium-maturity hybrids had slightly higher protein concentration than late-maturity hybrids, probably associated with lower grain yields (Tables 5 and 6; McDermitt and Loomis, 1981). Starch concentrations were greater for grain produced by food-grade hybrids, while the maturity classification had little effect (Table 8). Although the average was similar, food-grade hybrids had a wider range of protein and starch concentrations than non-food-grade hybrids (Table 7), thus high protein or starch concentration could be achieved by selecting the best hybrids. In most cases, an inverse relationship between protein and 
Table 7. Hybrid contrast comparisons for yield and grain quality of sorghum.

\begin{tabular}{|c|c|c|c|c|c|c|c|}
\hline Contrast comparisons & Yield & Kernel mass & Bulk density & True density & TADD $^{\dagger}$ & Protein & Starch \\
\hline & $\mathrm{Mg} \mathrm{ha}^{-1}$ & g 1000 kernels $^{-1}$ & $\mathrm{~kg} \mathrm{~m}^{3}$ & $\mathrm{~g} \mathrm{~mL}^{-1}$ & $\%$ removed & \multicolumn{2}{|c|}{$\mathrm{g} \mathrm{kg}^{-1}$} \\
\hline Food-grade hybrids versus & 7.4 & 21.8 & 773 & 1.344 & 24 & 102 & 697 \\
\hline Check hybrids & 7.8 & 24.2 & 784 & 1.351 & 22 & 103 & 695 \\
\hline$p$-value & $<0.01$ & $<0.01$ & $<0.01$ & $<0.01$ & $<0.01$ & $N S^{\ddagger}$ & $<0.01$ \\
\hline Food-grade hybrids versus & 7.4 & 21.8 & 773 & 1.344 & 24 & 102 & 697 \\
\hline Food-grade check (Macia) & 6.7 & 22.8 & 782 & 1.362 & 20 & 107 & 685 \\
\hline$p$-value & $<0.01$ & NS & $<0.01$ & $<0.01$ & $<0.01$ & $<0.01$ & $<0.01$ \\
\hline Medium maturity versus & 7.4 & 23.0 & 779 & 1.348 & 24 & 103 & 697 \\
\hline Late maturity & 7.8 & 22.2 & 773 & 1.347 & 22 & 101 & 696 \\
\hline$p$-value & $<0.01$ & $<0.01$ & $<0.01$ & NS & $<0.01$ & $<0.01$ & NS \\
\hline Medium-maturity food-grade hybrids versus & 7.3 & 22.6 & 775 & 1.343 & 25 & 103 & 697 \\
\hline Late-maturity food-grade hybrids & 7.6 & 20.2 & 768 & 1.346 & 24 & 100 & 697 \\
\hline$p$-value & $<0.01$ & $<0.01$ & $<0.01$ & 0.02 & 0.04 & $<0.01$ & NS \\
\hline Medium-maturity non-food-grade hybrids versus & 7.6 & 23.8 & 785 & 1.352 & 23 & 103 & 696 \\
\hline Late-maturity non-hood-grade hybrids & 8.1 & 25.1 & 780 & 1.351 & 21 & 103 & 694 \\
\hline$p$-value & $<0.01$ & $<0.01$ & $<0.01$ & NS & 0.04 & NS & 0.05 \\
\hline
\end{tabular}

TTADD, tangential abrasive dehulling device.

‡NS, not significant.

Table 8. Hybrid influence on yield and yield components, hardness parameters, and starch and protein concentrations (averaged over 12 environments).

\begin{tabular}{|c|c|c|c|c|c|c|c|}
\hline Hybrid & Yield & Kernel mass & Bulk density & True density & TADD $^{\dagger}$ & Protein & Starch \\
\hline Food-grade hybrids: & Mg ha $^{-1}$ & g 1000 kernels $^{-1}$ & $\mathrm{~kg} \mathrm{~m}^{-3}$ & $\mathrm{~g} \mathrm{~mL}^{-1}$ & $\%$ removed & \multicolumn{2}{|c|}{$\mathrm{g} \mathrm{kg}^{-1}$} \\
\hline Sorghum Partners NK 8828 & 7.2 & 19.9 & 763 & 1.342 & 25 & 107 & 685 \\
\hline Asgrow Eclipse & 7.1 & 20.3 & 780 & 1.347 & 23 & 100 & 703 \\
\hline Asgrow Orbit & 6.9 & 23.3 & 784 & 1.351 & 21 & 111 & 690 \\
\hline Kelly Green Seed KG6902 & 7.8 & 23.1 & 773 & 1.345 & 25 & 97 & 705 \\
\hline Fontanelle W-1000 & 7.8 & 22.0 & 778 & 1.342 & 26 & 95 & 707 \\
\hline $\mathrm{NC}+7 \mathrm{~W} 92$ & 7.3 & 22.2 & 763 & 1.336 & 27 & 97 & 703 \\
\hline Sorghum Partners NK 1486 & 6.9 & 23.2 & 764 & 1.342 & 28 & 112 & 684 \\
\hline Dekalb 44-41 & 7.7 & 24.4 & 782 & 1.339 & 24 & 104 & 696 \\
\hline Mycogen 14665 & 7.9 & 17.7 & 769 & 1.350 & 21 & 97 & 701 \\
\hline Food-grade check: Macia & 6.7 & 22.8 & 782 & 1.362 & 19 & 107 & 685 \\
\hline \multicolumn{8}{|l|}{ Non-food-grade hybrids (checks): } \\
\hline Dekalb 54-00 & 8.0 & 24.9 & 779 & 1.352 & 22 & 105 & 694 \\
\hline Dekalb 42-20 & 7.6 & 24.5 & 798 & 1.363 & 20 & 103 & 695 \\
\hline Dekalb 53-11 & 7.7 & 27.8 & 786 & 1.348 & 21 & 104 & 699 \\
\hline $\mathrm{NC}+6 \mathrm{C69}$ & 7.2 & 20.4 & 787 & 1.358 & 23 & 105 & 696 \\
\hline Pioneer 84Y00 & 8.2 & 25.3 & 782 & 1.349 & 20 & 101 & 693 \\
\hline Mycogen 3696 & 7.9 & 22.4 & 771 & 1.337 & 29 & 101 & 692 \\
\hline $\operatorname{LSD}(0.05)$ & 0.4 & 1.01 & 6.4 & 0.0058 & 1.63 & 2.7 & 4.5 \\
\hline
\end{tabular}

TTADD, tangential abrasive dehulling device.

starch concentrations appeared to be present. Food-grade hybrids with high amounts of starch and low amounts of protein that could be converted to fermentable sugars would be desirable to brewers (Agu and Palmer, 1998).

\section{Hybrid $\times$ Environment Interaction}

The ANOVA indicated that the hybrid $\times$ genotype interaction effects made up less than $2 \%$ of the total variation for all parameters measured (Table 4) and thus was of minor importance. Partitioning of the mean squares for the interaction indicated that differences were present for food-grade and non-food-grade hybrids and hybrid maturity. Grain yield and hardness increased as the environment mean increased (Fig. 1 and 2). Non-food-grade hybrids produced higher grain yield across all environments, with the difference in yield being slightly less as the environment mean yield increased (Fig. 1A). Both maturities produced similar yields in low-yielding environments while late-season hybrids produced greater yields as the environment mean yield increased (Fig. 1B). The late-season hybrids produced $0.7 \mathrm{Mg} \mathrm{ha}^{-1}$ greater yield in the highest yield environments. Grain hardness, as measured by true density, was greater for 

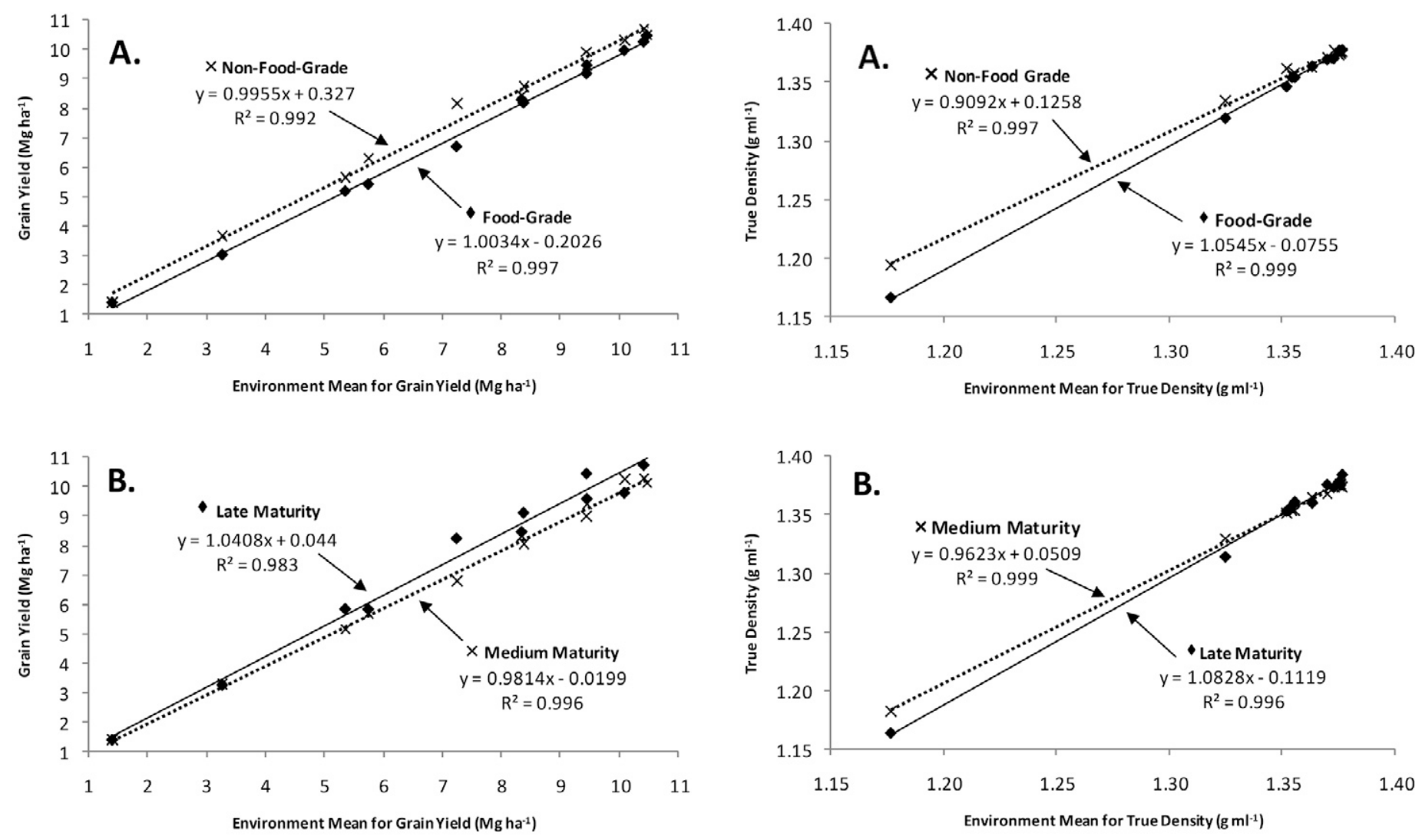

Fig. 1. Influence of food-grade and non-food-grade hybrid and hybrid maturity on sorghum grain yield.

non-food-grade (Fig. 2A) and medium-maturity (Fig. 2B) hybrids when environmental means were lower (i.e., softer) and decreased as the environmental mean increased, with little or no difference in true density when environmental means were high. Similar results were found for the other hardness parameters, bulk density, and TADD removal (data not presented).

\section{Correlation Analysis}

Pearson correlations indicated that grain yield was positively associated with kernel mass (Table 9) as previously reported (Larson and Vanderlip, 1994; Lesoing and Francis, 1999; Rajewski et al., 1991; Maman et al., 2004; Saeed et al., 1987). Hardness parameters were highly correlated to each other and to yield and kernel mass. Both bulk and true density had high negative correlation with TADD removal, similar to the results of Almeida-Dominguez et al. (1991) in maize and Kaye et al. (2007) in sorghum but contrasting with the results of Buffo et al. (1998).

Grain yield was correlated with all parameters measured except protein concentration (Table 9). As expected, hardness parameters were highly correlated with each other (Kaye et al., 2007) and with starch concentration. Kernel mass had high correlation with hardness parameters and starch concentration and low correlation with protein concentration. The kernel mass correlations with starch and protein concentration were in contrast with

Fig. 2. Influence of food-grade and non-food-grade hybrid and hybrid maturity on sorghum grain true density.

the results of Kriegshauser et al. (2006). Protein concentration had low but significant correlations with hardness parameters, in contrast with the results of Kaye et al. (2007), Buffo et al. (1998), and Beta et al. (1995). Protein concentration had low correlation with kernel mass and bulk and true densities, in contrast with other studies (Kaye et al., 2007; Duarte et al., 2005). Protein concentrations were generally negatively correlated with starch concentration, with the exception of the Mead dryland with low-N 2004 environment, which had both low protein and starch concentrations. Starch concentration was relatively highly associated with grain yield, kernel mass, and hardness parameters, which is consistent with previous research that starch concentration increases with grain yield (McDermitt and Loomis, 1981) and that starch has higher density than protein (Hoseney, 1994).

\section{CONCLUSION}

The environment in which food-grade sorghum is produced clearly contributes much more heavily to variation in yield and quality traits than hybrid selection or hybrid $\times$ environment interactions. Of the four major U.S. growing states (Texas, Kansas, Oklahoma, and Nebraska), Nebraska average yield is highest with statewide yields averaging $3.3,4.9,2.8$, and $5.7 \mathrm{Mg} \mathrm{ha}^{-1}$, respectively, in 2008 (USDA National Agricultural Statistics Service, 2009). Climatic conditions in this northernmost of the 
Table 9. Pearson correlations and probability levels for yield, kernel mass, hardness parameters, and proximate analysis.

\begin{tabular}{|c|c|c|c|c|c|c|}
\hline & Yield & Kernel mass & Bulk density & True density & $\mathrm{TADD}^{\dagger}$ removal & Protein \\
\hline Kernel mass & $0.56^{\star \star}$ & & & & & \\
\hline Test weight & $0.58^{\star \star}$ & $0.77^{* *}$ & & & & \\
\hline True density & $0.64^{\star *}$ & $0.77^{* *}$ & $0.95^{\star *}$ & & & \\
\hline TADD removal & $-0.59^{\star \star}$ & $-0.74^{\star \star}$ & $-0.92^{\star \star}$ & $-0.95^{\star \star}$ & & \\
\hline Protein & 0.02 & $0.13^{\star \star}$ & $0.12^{\star \star}$ & $0.15^{\star \star}$ & $-0.24^{\star \star}$ & \\
\hline Starch & $0.49^{\star \star}$ & $0.49^{\star *}$ & $0.61^{* \star}$ & $0.64^{\star *}$ & $-0.60^{\star \star}$ & $-0.31^{\star \star}$ \\
\hline
\end{tabular}

**Significant at the 0.01 level of probability.

TTADD, tangential abrasive dehulling device.

major sorghum producing states during grain maturation and dry-down periods are typically dry and cool (Tables 1 and 2). The combination of high yield potential and climatic conditions less favorable for grain weathering have contributed to south-central Nebraska becoming a recognized center for the new and small market food-grade sorghum with the establishment of flour production at Twin Valley Mills (Twin Valley Mills LLC, 2009). This market has great potential for expansion in the near future.

Although of secondary importance, choice of foodgrade sorghum hybrids is an important decision both for high yield and specific grain quality attributes. In this study, Asgrow Orbit and the food-grade check Macia produced the hardest kernels desired for dry-milled food products. Kelly Green Seed KG6902, NC+7W92, and Fontanelle W-1000 had lower protein and higher starch concentrations, indicating that they should be well suited for brewing. The hybrid $\times$ genotype interaction made up less than $2 \%$ of the total variation and thus was of minor importance, although non-food-grade and mediummaturity hybrids produced harder grain in environments with lower environmental means.

The results of this study demonstrate that selection or manipulation of sorghum production environments within the high-yielding Nebraska area can contribute strongly toward producers achieving quality parameters for specific markets. Dryland environments can be selected to produce harder kernels useful for dry milling food purposes. Alcohol production for beer or ethanol works best with sorghum that is high in starch and low in protein, which can be produced in low- $\mathrm{N}$ environments with an adequate water supply. Nebraska production environments have the capability to produce high-quality foodgrade sorghums with marketable traits for specific food uses to benefit both the producer and the food processor.

\section{References}

Agu, R.C., and G.H. Palmer. 1998. A reassessment of sorghum for lager-beer brewing. Bioresour. Technol. 66:253-261.

Almeida-Dominguez, H.D., S.O. Serna-Saldivar, and L.W. Rooney. 1991. Properties of new and commercial sorghum hybrids for use in alkaline-cooked foods. Cereal Chem. 68:25-30.

Bauer, P.J., and P.R. Carter. 1986. Effect of seeding date, plant density, moisture availability and soil nitrogen fertility on maize kernel breakage susceptibility. Crop Sci. 26:1220-1226.

Beta, T., L.W. Rooney, and R.D. Waniska. 1995. Malting characteristics of sorghum cultivars. Cereal Chem. 72:533-538.

Bewley, J.D., and M. Black. 1994. Seeds: Physiology of development and germination. Plenum Press, New York.

Budak, N., P.S. Baenziger, K.M. Eskridge, D. Baltensperger, and B. Moreno-Sevilla. 1995. Plant height response of semidwarf and on semidwarf wheats to environment. Crop Sci. 35:447-451.

Buffo, R.A., C.L. Weller, and A.M. Parkhurst. 1998. Relationships among grain sorghum quality factors. Cereal Chem. 75:100-104.

Dlamini, N.R., J.R.N. Taylor, and L.W. Rooney. 2007. The effect of sorghum type and processing on the antioxidant properties of African sorghum-based foods. Food Chem. 105:1412-1419.

Duarte, A.P., S.C. Mason, D.S. Jackson and J. de C Kiehl. 2005. Grain quality of Brazilian maize genotypes as influenced by nitrogen level. Crop Sci. 45:1958-1964.

Duvick, D.N. 2005. The contribution of breeding to yield advances in maize (Zea mays L.). Adv. Agron. 86:83-145.

Duvick, D.N., and K.G. Cassman. 1999. Post-green revolution trends in yield potential of temperate maize in the north-central United States. Crop Sci. 39:1622-1630.

Fasano, A., and C. Catassi. 2001. Current approaches to diagnosis and treatment of celiac disease: An evolving spectrum. Gastroenterology 120:636-651.

Figueroa, J.D.C., B.F. Martinez, and E. Rios. 1995. Effect of sorghum endosperm type on the quality of adjuncts for the brewing industry. J. Amer. Soc. Brewing Chemists 53:5-9.

Fox, S.R., L.A. Johnson, C.R.J. Hurburgh, C. Dorsey-Redding, and T.B. Bailey. 1992. Relations of grain proximate composition and physical properties to wet-milling characteristics of maize. Cereal Chem. 69:191-197.

Garrity, D.P., C.Y. Sullivan, and D.G. Watts. 1983. Moisture deficits and grain sorghum performance: Drought stress conditioning. Agron. J. 75:997-1004.

Hall, M. B. 2001. Factors affecting starch analysis of feeds. Inst. Food Agric. Sci., Publ. No. AS121. Univ. of Florida, Gainesville, FL.

Hanson, R.G., J.A. Stecker, and S.R. Maledy. 1988. Effect of soybean rotation on the response of sorghum to fertilizer nitrogen. J. Prod. Agric. 1:318-321.

Hattendorf, M.J., M.S. Redelfs, B. Amos, L.R. Stone, and R.E.J. Gwin. 1988. Comparative water use characteristics of six row crops. Agron. J. 80:80-85.

Hoseney, R.C. 1994. Principles of cereal science and technology. Amer. Assoc. Cereal Chemists, St. Paul, MN.

Johnson, W.B. 2005. The influence of corn and sorghum characteristics on wet milling and nixtamalization performance. 
M.S. thesis. Univ. of Nebraska, Lincoln, NE.

Kamoshita, A., S. Fukai, R.C. Muchow, and M. Cooper. 1998. Genotypic variation for grain yield and grain nitrogen concentration among sorghum hybrids under different levels of nitrogen fertilizer and water supply. Aust. J. Agric. Res. 49:737-747.

Kaye, N.M., S.C. Mason, D.S. Jackson, and T.D. Galusha. 2007. Crop rotation and soil amendment alters sorghum grain quality. Crop Sci. 47:722-729.

Kiniry, J.R. 1988. Kernel weight increase in response to decreased kernel number in sorghum. Agron. J. 80:221-226.

Kniep, K.R., and S.C. Mason. 1989. Kernel breakage and density of normal and opaque-2 maize grain as influenced by irrigation and nitrogen. Crop Sci. 29:158-163.

Kriegshauser, T.D., J.D. Hancock, and M.R. Tuinstra. 2006. Variation in nutritional value of sorghum hybrids with contrasting seed weight characteristics and comparisons with maize in broiler chicks. Crop Sci. 46:695-699.

Larson, E.J., and R.L. Vanderlip. 1994. Grain sorghum yield response to nonuniform stand reductions. Agron. J. 86:475-477.

Lesoing, G.W., and C.A. Francis. 1999. Strip intercropping effects on yield and yield components of corn, grain sorghum, and soybean. Agron. J. 91:807-813.

Littell, R.C., G.A. Milliken, W.W. Stroup, and R.D. Wolfinger. 1996. SAS system for mixed models. SAS Institute, Cary, NC.

Lochte-Watson, K.R., D.S. Jackson, and C.L. Weller. 2000. Fractionation of grain sorghum using abrasive decortication. J. Agric. Eng. Res. 77:203-208.

Maman, N., S.C. Mason, D.J. Lyon, and P. Dhungana. 2004. Yield components of pearl millet and grain sorghum across environments in the central Great Plains. Crop Sci. 44:2138-2145.

Maranville, J.W., R.B. Clark, and W.M. Ross. 1980. Nitrogen efficiency in grain sorghum. J. Plant Nutr. 2:577-589.

McDermitt, D.K., and R.S. Loomis. 1981. Elemental composition of biomass and its relation to energy content, growth efficiency, and growth yield. Ann. Bot. (London) 48:275-290.

Montgomery, D.C. 2005. p. 79. Design and analysis of experiments, 6th ed. John Wiley \& Sons, New York.

Padmore, J.M. 1990. Protein (crude) in animal feed-Dumas method, Method No 968.06. p. 71-72. In K. Herlich (ed.) Official methods of analysis of the association of official analytical chemists, 15th ed. AOAC, Inc., Arlington, VA.

Rajewski, J.F., C.A. Francis, and J.D. Eastin. 1991. Differential responses to defoliation of grain sorghum yield components and yield related traits. Crop Sci. 31:561-567.

Rooney, L.W. 1996. Attributes of improved quality sorghums for value-added marketing. p. 112-124. Proc. Annu. Corn Sorghum Res. Conf., 51 st Chicago. 10 Dec. 1996. Am. Seed Trade Assoc., Washington, DC.

Rooney, L.W., and J.M. Awika. 2005. Overview of products and health benefits of specialty sorghums. Cereal Foods World 50:109-115.

Saeed, M., C.A. Francis, and J.F. Rajewski. 1984. Maturity effects of genotype $\times$ environment interactions in grain sorghum. Agron. J. 76:55-58.

Saeed, M., C.A. Francis, J.F. Rajewski, and J.W. Maranville. 1987. Genotype $\times$ environment interaction and stability analysis of protein and oil in grain sorghum. Crop Sci. 27:169-171.

Scheffé, H. 1959. p. 338- 340. The analysis of variance. John Wiley \& Sons, New York.

Shandera, D.L., D.S. Jackson, and B.E. Johnson. 1997. Quality factors impacting processing of maize dent hybrids. Maydica 42:281-289.

Taylor, F.R.N., J. Dewar, J. Taylor, and R.F. von Ascheraden. 1997. Factors affecting the porridge-making quality of South African sorghums. J. Sci. Food Agric. 73:464-470.

Twin Valley Mills, LLC. 2009. Home Page. Available at http:// www.twinvalleymills.com/ (verified 27 Mar. 2010). Twin Valley Mills, LLC, Ruskin, NE.

USDA. 1998. Estimating soil moisture by feel and appearance. Program aid. USDA, Washington, DC.

USDA National Agricultural Statistics Service. 2009. U.S. and all states data-crops. Available at http://www.nass.usda.gov/ QuickStats/PullData_US.jsp (verified 27 Mar. 2010). USDANASS, Washington, DC.

Wilhelm, L.R., D.A. Suter, and G.H. Brusewitz. 2004. Food \& process engineering. Amer. Soc. Agric. Eng. St. Joseph, MI.

Wortmann, C.S., A.R. Dobermann, R.B. Ferguson, G.H. Hergert, C.A. Shapiro, and D. Tarkalson. Fertilizer suggestions for grain sorghum. NebGuide G1669. 2006. Coop. Ext. Service, Univ. of Nebraska, Lincoln, NE. 